\title{
An Investigation of Drivers and Barriers Stimulating in the Acceptance of Mobile Payment in Bangladesh
}

\author{
Mohammad Majedul Islam \\ Department of Marketing, University of Rajshahi, Bangladesh
}

Copyright $(2016$ by authors, all rights reserved. Authors agree that this article remains permanently open access under the terms of the Creative Commons Attribution License 4.0 International License

\begin{abstract}
Bangladesh is one of the highest mobile phone users' countries among ten in the world where mobile payment service is becoming a promising area with the speedy rise of mobile internet. Conversely, various researches on mobile phone users acceptance of mobile payment has not reveal clearly to a definite assumption for Bangladesh context considering technology acceptance model (TAM). A survey has conducted to collect data from 260 consumers of Bangladesh and then hypothesized model based on data analysis in SPSS. It has found that perceived ease of use and perceived usefulness are the drivers in the acceptance of mobile payment where subjective norms mediate them. Alternatively, perceived risk and perceived costs are treated as barriers toward behavioral intention to use mobile payment. This study explores new results in the TAM model in Bangladesh context and provided managerial insights to the mobile payment service providers to develop strategies in Bangladesh.
\end{abstract}

Keywords Mobile Payment (MP), Consumer Acceptance, Drivers, Barriers, Technology Acceptance Model (TAM), Bangladesh

\section{Introduction}

Mobile payment (m-payment) is payment of train fare, parking, shopping and digital contents. Mobile payment services conducted via a mobile device - have been a key driver in socioeconomic development in emerging markets. Mobile payments is widely tipped to become a hot growth area for telecom business, and in some markets in Asia Pacific it already is, from smart-card-based mobile wallet services in Japan and Korea to remittance payment services in Southeast Asia. But it's early days, and the mobile payment pie is going to get a whole lot bigger. It has projected that global mobile payment revenue grow from $\$ 47.2$ billion in 2011 to $\$ 998.5$ billion in 2016 (Roberts, 2013) and forecasted value of global m-payment transactions to pass $\$ 958$ billion by 2015 at a growth rate of $97 \%$ a year
[74]. World is focusing towards developing countries to lead this mobile payment services. Kenya is leading the world in Mobile Money service through M-PESA since 2007 to allow microfinance-loan repayments [70]. It was then imitated by Philippine, India, Bangladesh and Pakistan.

In Bangladesh, bKash has succeeded to launch mobile payment service as part of mobile financial services in 2011 [19]. The service launched will facilitate faster transfer of money from almost every country to Bangladesh. Bangladesh is well headed in adopting new business of mobile phone and introduced Mobile payment with or without direct involvement of mobile network operators (MNOs). Mobile payment adoption appears strongest in Asia where Bangladesh and Pakistan have more than half of all mobile consumers registered their phones to make purchases [66].

Ten Banks and six MNOs have introduced Mobile payment service in Bangladesh and most of them emphasis on person to person (P2P) payment. Within one year after introducing Mobile Money, the market has 442,289 registered customers, 9,093 appointed agents and rolled TK. 20.71 million till March, 2012 [52]. Although people are more concern to $\mathrm{P} 2 \mathrm{P}$ using Mobile payment service; there is a scope of more services permitted by Bangladesh Bank related to m-payment. When compared with the global leader Kenya, mobile financial services in Bangladesh has a lot of room to grow before it can claim any wide national impact. For instance, while $35 \%$ of Kenyan mobile money users use their accounts for advanced functions such as purchasing goods, receiving salaries and taking loans, in Bangladesh, mobile money use is heavily based on person-to-person transfers [35].

The growing rate of m-transfer and m-payment and the facilities provided by to Banks and MNOs will support enhancement of E-Marketing. As most of the people of Bangladesh are staying rural areas earning low amount of income and less educated mobile payment is not expanding with the availability of internet. People are now experienced to send/receive money as balance transfer, Bangladesh Post Office (BPO) service and mobile ticketing system. Now, it is the turn to develop merchant payment through using mobile 
payment service. But the trend of the transaction is very leisurely and it needs to minimize the gaps through positive mind set up towards mobile payment. For this reason the study needs to focus on finding drivers and barriers of mobile payment acceptance in Bangladesh. This research is highly attention to make a link those drivers and barriers with the impacts on mobile payment acceptance so that researchers and managers will have better outcomes to improve their research potentials or customers satisfactions.

\subsection{Literature Review and Hypothesis Development}

The mobile payment research has been streamed in two ways. It has measure as the mobile technology in constant evolution of mobile payment system [45]; others are concerned on the consumer acceptance of the technology with various empirical models based on Technology Acceptance Model (TAM), Theory of Planned Behaviour (TPB), and Innovation Diffusion Theory (IDT). Conversely, many empirical researchers bring out different antecedents of the mobile payment acceptance. This study reviewed several researches from 1999 to 2013 done in Europe, America, Asia, and Australia those have been developed a number of models attempted to understand factors influencing acceptance of mobile commerce. Among this TAM is mostly robust in explaining acceptance of mobile payment services. However, the original model has had to be revised to examine other aspects. This study explored that the same factors may be validated in different papers to have a positive, negative or insignificant effect on mobile payment acceptance. For example, ease of use is a strong determinant of behavioral intention [3] but it has been verified empirically to be insignificant in different studies [25] [85]. The effect of usefulness is mostly a significant factor of behavioral intention whereas it found insignificant at $\mathrm{P}<0.05$ level [51]. What on earth are the factors that drive or obstruct the acceptance of consumers to use mobile payment in Bangladesh? This research attempts to examine this concern.

The number of studies on mobile payment acceptance in Bangladesh is very limited and most of the studies analyze concentrating on other service of mobile commerce. Furthermore, a few studies concern mobile payment overview in Asian perspective and most are concern on developed countries. There is no research found related to high concentration of m-payment and its acceptance in the context of Bangladesh. In this backdrop the main reason for undertaking the study is planned to identify and relate the drivers and barriers in the acceptance of mobile payment in Bangladesh.

\subsection{Technology Acceptance Model (TAM)}

The Technology Acceptance Model (TAM) is an information systems theory that models how users come to accept and use a technology [15]. The model had two main determinants which explain IT adoption: Perceived Usefulness and Perceived Ease of Use. Perceived usefulness is defined as being the degree to which a person believes that the use of a system will improve his performance. Perceived ease of use refers to the degree to which a person believes that the use of a system will be effortless. Several factorial analyses demonstrated that perceived usefulness and perceived ease of use can be considered as two different dimensions [23].

Davis reported that the relationship between perceived usefulness and adoption was significantly stronger than that of between perceived ease of use and adoption. Furthermore, he noted that perceived ease of use might even precede perceived usefulness, suggesting the existence of a causal relationship instead of the independence of the driving forces. Perceived usefulness is considered to have a positive effect on intention to use a technology. It is a measure of the subjective assessment of the utility offered by the technology.

Perceived usefulness is a significant determinant of attitude and intention [25] [11] [85] [32] [3] [63] [34] [14] and [71]. Perceived ease of use is the degree to which a person believes that adopting the system will be free of effort. Perceived ease of use has both an immediate effect and an indirect effect on adoption intention through mediating perceived usefulness [3] [34] [14]. Social and organizational variable such as subjective norm has shown direct impact on perceived usefulness and perceived ease of use. It is the most influential factor to mediate perceived usefulness and perceived ease of use to have direct impact on behavioral intention towards mobile payment use [63] [69] [67]. This research focuses on the key determinants of mobile payment acceptance and examined user acceptance considering behavioral intention and actual use in Bangladesh. Therefore, based on TAM, this study hypothesizes:

$\mathrm{H}_{1}$ : Behavioral intention has a significant positive effect on actual use of mobile payment in Bangladesh

$\mathrm{H}_{2}$ : Perceived usefulness has a significant positive effect on behavioral intention of mobile payment in Bangladesh

$\mathrm{H}_{3}$ : Perceived ease of use has a significant positive effect on behavioral intention of mobile payment in Bangladesh

$\mathrm{H}_{4}$ : Perceived ease of use has a significant positive effect on perceived usefulness of mobile payment in Bangladesh

$\mathrm{H}_{5}$ : Subjective norms have a significant effect on perceived usefulness of mobile payment in Bangladesh

$\mathrm{H}_{6}$ : Subjective norms have a significant effect on perceived ease of use of mobile payment in Bangladesh 
Table 1. Literature review summary

\begin{tabular}{|c|c|c|c|}
\hline Authors & Theories & Sampling \& Countries & Major Findings \\
\hline $\begin{array}{l}\text { (Hu, Chau, Sheng, } \\
\text { \& Tam, 1999) }\end{array}$ & TAM & $\begin{array}{c}\text { Nine Physicians departments, } \\
\text { Hong Kong }\end{array}$ & $\begin{array}{l}\text { PU is a significant determinant of attitude and intention, but } \\
\text { PEOU is not. }\end{array}$ \\
\hline (Chau \& Hu, 2001) & $\begin{array}{l}\text { TAM, TPB, and } \\
\text { IDT }\end{array}$ & $\begin{array}{c}\text { Survey of } 400 \text { physicians, Hong } \\
\text { Kong }\end{array}$ & PU has positive effects on attitude and behavioral intention. \\
\hline $\begin{array}{l}\text { (Yi, Jackson, Park, } \\
\text { \& Probst, 2006) }\end{array}$ & TAM and TPB & $\begin{array}{l}\text { Survey of } 222 \text { resident and faculty } \\
\text { doctors, USA }\end{array}$ & $\begin{array}{l}\text { PU has a positive effect on behavioral intention, but PEOU does } \\
\text { not. }\end{array}$ \\
\hline (Klein, 2007) & TAM & Survey of 294 patients, USA & PU has a positive effect on behavioral intention. \\
\hline $\begin{array}{l}\text { (Amin, M. R. A., S, } \\
\text { \& Z., 2008) }\end{array}$ & TAM & Survey in Malaysia & $\begin{array}{l}\text { Perceived usefulness and perceived ease of use are strong } \\
\text { determinants of behavioral intention to adopt mobile banking. }\end{array}$ \\
\hline $\begin{array}{l}\text { (Alda's-Manzano, } \\
\text { J., \& Sanz-Blas, } \\
\text { 2009) }\end{array}$ & TAM & Survey of 470, Span & $\begin{array}{c}\text { Personality variables have a direct and positive influence on the } \\
\text { intention to engage in M-shopping }\end{array}$ \\
\hline $\begin{array}{c}\text { (Riquelme \& R. E., } \\
2010)\end{array}$ & $\begin{array}{l}\text { TAM, TPB, and } \\
\text { IDT }\end{array}$ & 681 samples, Singapore & $\begin{array}{l}\text { Usefulness, social norms, risk influences the intention to adopt } \\
\text { mobile banking }\end{array}$ \\
\hline $\begin{array}{l}\text { (Koening-Lewis, } \\
\text { A., \& A., 2010) }\end{array}$ & TAM and IDT & 155 consumers in Germany & $\begin{array}{l}\text { perceived usefulness, compatibility, and risk are significant } \\
\text { factors, while perceived costs, easy-of-use, credibility, and trust } \\
\text { are not salient factors }\end{array}$ \\
\hline $\begin{array}{l}\text { (Sripalawat, M., \& } \\
\text { A., 2011) }\end{array}$ & TAM and TPB & 195 online survey in Thailand & $\begin{array}{l}\text { Subjective norm is the most influential factor; the following is } \\
\text { perceived usefulness and self-efficacy. }\end{array}$ \\
\hline $\begin{array}{l}\text { (Dasgupta, R., \& S., } \\
\text { 2011) }\end{array}$ & TAM & 325 MBA students in India & $\begin{array}{l}\text { Perceived usefulness, easy-of-use, image, value, self-efficacy, } \\
\text { and credibility significantly affect intentions toward mobile } \\
\text { banking usage. }\end{array}$ \\
\hline $\begin{array}{l}\text { (Stalfors \& Nykvist, } \\
\text { 2011) }\end{array}$ & $\begin{array}{l}\text { TRA, TPB and } \\
\text { TAM }\end{array}$ & 320 respondents in Sweden & $\begin{array}{l}\text { Perceived Compatibility and Perceived Usefulness are the main } \\
\text { determents for consumers' acceptance of mobile payment } \\
\text { service. Perceived Security is supported and important more to } \\
\text { older than younger generations }\end{array}$ \\
\hline (Shatskikh, 2013) & TAM & 300 online survey, USA & $\begin{array}{l}\text { Security, the subjective norm, compatibility with consumers' } \\
\text { lifestyles, and previous experience with MPs were added to the } \\
\text { traditional two-factor TAM }\end{array}$ \\
\hline
\end{tabular}

\subsection{Perceived Risk and Cost}

Perceived risk (PR) is universally acknowledged to be introduced by Bauer in 1960 [18] which refers to the extent to the prospective user expects the services to be risky. Perceived risk as a direct antecedent of consumers' intention to accept online transaction [57]. Perceived security risk is a vital determinant for mobile payment acceptance which has 6 contributing factors, namely, unauthorized use, transaction errors, lack of transaction record and documentation, vague transactions, concerns on device and network reliability and concerns on privacy [47]. It is also a critical factor in mobile commerce acceptance in Taiwan [39] [29]. There are $48 \%$ of the cellular users who refuse to use mobile payment services are due to security issue. Perceived risk is a key barrier to mobile payment acceptance in Bangladesh too.

Perceived cost refers to the extent to which people believe that use of mobile payment services will have monetary cost. It is considered as an important factor affecting user's behavioral intention to mobile payment [73] [47] and in similar domains like 3G mobile value-added services [37], $3 \mathrm{G}$ phones [81] mobile banking [56], and mobile commerce [29]. Consumers intend to accept mobile payment services when they perceived it as cost-effective. Consequently, the hypotheses on perceived risk and perceived cost will be:

$\mathrm{H}_{7}$ : Perceived risk has negative affect on behavioral intention of mobile payment in Bangladesh.

$\mathrm{H}_{8}$ : Perceived cost has negative affect on behavioral intention of mobile payment in Bangladesh.

\subsection{Research Model}

The technology acceptance model shows that perceived usefulness and perceived ease of use has direct relation to behavioral intention and behavioral intention has direct impact on actual use. There are some other research found social influence or a subjective norm also has direct relation to both perceived usefulness and perceived ease of use.

This research tries to find out negative relation between barriers and behavioral intention too. So, perceived risk and perceived cost has negative impact on behavioral intention. Considering the above hypotheses, the research model of this paper is presented as figure 2 . The perceived risks and perceived costs are added with the existing TAM theory to find out the impact in Bangladesh context. 


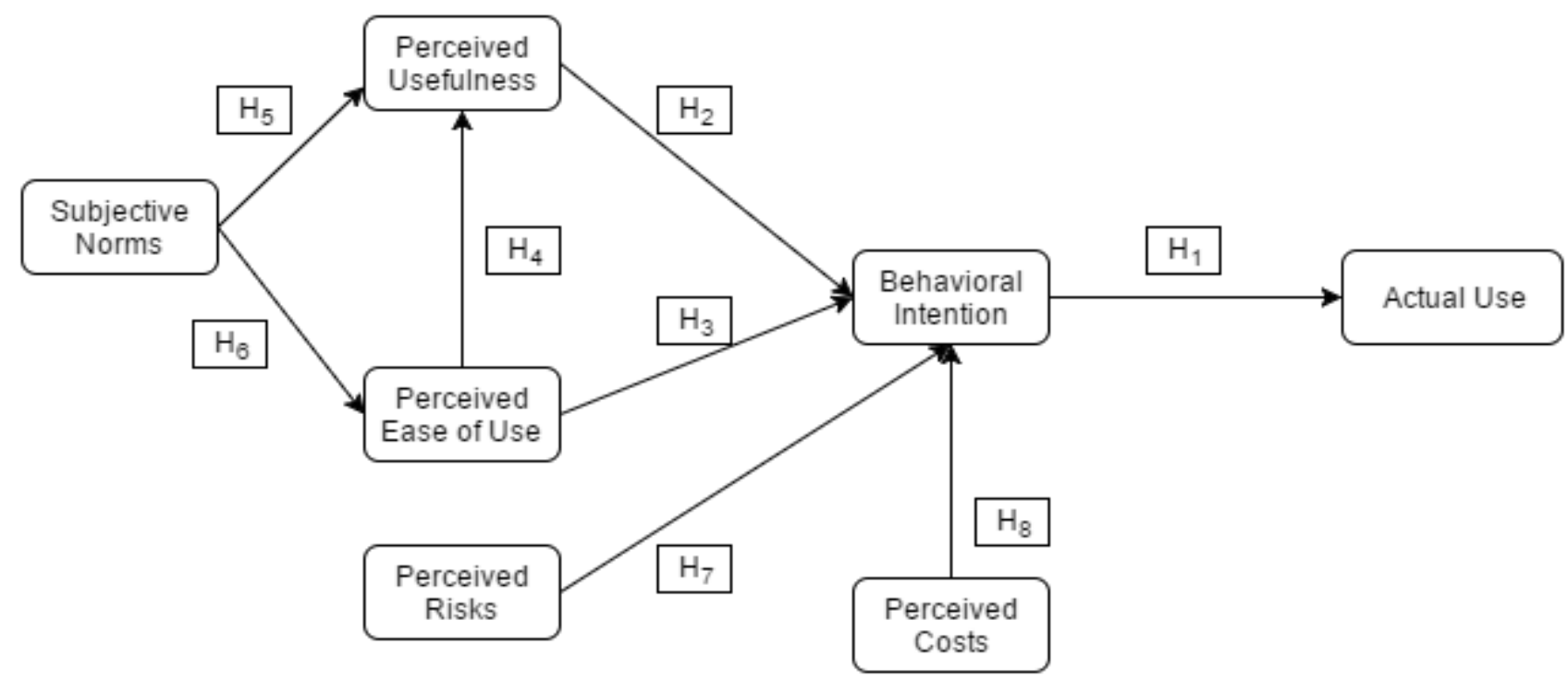

Figure 2. The research model

\section{Research Methodology}

The study has covered selection of sample, nature \& sources of data, developing data collections, interview schedules, pilot study use, and techniques and process of data analysis.

\subsection{Questionnaire Development}

The questions in the questionnaire were based on review of literatures and the specific characteristics of Bangladeshi people \& market context. The specific characteristics represented different services and facilities provided by the MFS institutions and expected by the MFS consumers of Bangladesh. The questionnaire was translated into Bengali language to make clear and simple to understand by every respondent. The items in the questionnaire were constructed based on the consumer attitude and acceptance of m-commerce services through mobile payment.

\subsection{Sample Size}

The sample of the study were two mobile financial service (MFS) institutions \& mobile network operator (MNO) and 260 Customers of Mobile Money service of m-payment using different MNO and MFS.

\subsection{Data Sources}

This study will considered survey of randomly selected users from different regions of Bangladesh. The respondents verbally replied to a structured questionnaire and their answers were recorded accordingly by the interviewers. There were 30 questions relevant to the drivers and barriers along with behavioral intention and use behaviour. The data relevant to understanding and analyse the current status of mobile payment in Bangladesh have been composed from different secondary sources i.e. World Bank Report, Annual and Periodical Reports of Bangladesh Bank, Annual Report of Ministry of Finance of Bangladesh, Bangladesh Telecommunication Regulatory Commission (BTRC), Bangladesh Economic Survey and various published documents of financial services relevant to Banks and Mobile Network Operators (MNOs) in Bangladesh.

\subsection{Preparation of Data}

The research used one set of questionnaires (structured) for the customers using Mobile Payment services in Bangladesh. Five points Likert Scale used in preparing the study. The questionnaires set up in accordance with External Quality Assessment (EQA) criteria in order to be able to compute scores. For each criterion several questions need to be selected to obtain a valid representation of each individual criterion. Pilot Study has done for finalizing the survey schedule through discussion with the expert users of mobile payment services.

\subsection{Data Analysis}

As far as scale-based variables were concerned, principal factor analysis was performed. In this study, the correlation matrix was used to obtain Eigen values. To facilitate the interpretation of factor loading, VARIMAX rotation was performed. In addition, Pearson correlation analyses were also conducted to examine the relationships among the constructs. SPSS software version 20 was used for analysing the data.

\section{Analysis and Interpretation of Data}

\subsection{Descriptive Statistics}


The study were investigated demographic characteristics in regards to the respondents' gender, age, occupation, income, residence region, e-commerce service use, mobile network operator use, mobile financial service institute use, and number of monthly transaction. Missing values, outliers, and distribution of all the measured items were conducted to avoid the error of the estimates and also to purify the data.

The male and female ratio of the respondents was $69.2 \%$ and $30.8 \%$ respectively. It indicates that male respondents are using online shopping services more than female. Most of the respondents were at 18 to 25 years age range and $74.2 \%$ are students, which imply that mostly youth level students are using e-commerce services. Monthly income of the respondents is mostly less than BDT $10000(56.5 \%)$ and their residence regions are mostly Khulna (28.8\%), Rangpur (20.4\%), and Rajshahi (16.6\%). The e-commerce services using mobile money are mostly mobile top-up (39.6\%), send money (35.4\%), and utility service (10.8\%). Respondents are mostly using mobile financial service institute account of either DBBL (48.1\%) or bKash $(44.2 \%)$ to use mobile money for avail e-commerce services. Those who are availing e-commerce through mobile money are making five or less transactions $(86.9 \%)$ in a month.

\subsection{Reliability and Validity}

There are twenty four items have been considered for the study. Multi-item scales (Six Point Likert Scale) response format has been used to operationalize each individual item of the questionnaire.

Table 2. Reliability statistics of items

\begin{tabular}{|c|c|c|}
\hline \multicolumn{3}{|c|}{ Reliability Statistics } \\
\hline Cronbach's Alpha & $\begin{array}{c}\text { Cronbach's Alpha Based on } \\
\text { Standardized Items }\end{array}$ & $\begin{array}{c}\text { N of } \\
\text { Items }\end{array}$ \\
\hline 0.842 & 0.840 & 24 \\
\hline
\end{tabular}

The overall measurement for contextually formatted items is described in Table 2 result shows that scales used for the data collection are mostly reliable with highly recommended alpha scores which is within the range of good scale reliability [54].

The study identifies 33 items based on Eigenvalue - 1 or above includes into the list of items. Statistically 24 items construct seven factors which can explain $64.245 \%$ of the field. So, this study considers these factors are important for the study. Factor-1 explains $23.281 \%$ having Eigenvalue of 5.587and Factor-7 explains 4.265\% with Eigenvalue 1.024 as lowest (Table 4). Hence, factor-1 is the most important in the current study which is related to behavioral intention to use mobile payment in Bangladesh.

\subsection{Factor Analysis}

The results obtained from 260 respondents had been thoroughly analyzed. Applying SPSS, the Principal Component Analysis (PCA) was carried out to explore the underlying factors associated with 33 items. The constructs validity was tested applying Bartlett's Test of Sphericity and the Kaiser-Mayer-Olkin (KMO) measure of sampling adequacy analyzing the strength of association among variables. Result of the Bartlett's Test of Sphericity and $\mathrm{KMO}$ revealed that both were highly significant $(0.823)$ and eventually concluded that these variables was suitable for the factor analysis (Table 3).

Table 3. KMO and Bartlett's Test

\begin{tabular}{|c|c|c|}
\hline \multicolumn{3}{|c|}{ KMO and Bartlett's Test } \\
\hline Kaiser-Meyer-Olkin Measure of Sampling Adequacy. & 0.823 \\
\hline \multirow{2}{*}{$\begin{array}{c}\text { Bartlett's Test of } \\
\text { Sphericity }\end{array}$} & Approx. Chi-Square & 2164.345 \\
\cline { 2 - 3 } & df & 276 \\
\cline { 2 - 3 } & Sig. & 0.00 \\
\hline
\end{tabular}

Deciding upon the number of factors that can be retained is difficult but initial runs-based on Eigenvalues showed 7 factors explained $64.245 \%$ of total variance (Table 3 ).

Table 4. Eigen value and variability of the retained factors

\begin{tabular}{|c|c|c|c|c|c|c|}
\hline \multicolumn{9}{|c|}{ Total Variance Explained } \\
\hline \multirow{2}{*}{ Component } & \multicolumn{3}{|c|}{ Initial Eigenvalues } & \multicolumn{3}{c|}{ Extraction Sums of Squared Loadings } \\
\cline { 2 - 7 } & Total & $\%$ of Variance & Cumulative $\%$ & Total & $\%$ of Variance & Cumulative \% \\
\hline 1 & 5.587 & 23.281 & 23.281 & 5.587 & 23.281 & 23.281 \\
\hline 2 & 3.356 & 13.983 & 37.264 & 3.356 & 13.983 & 37.264 \\
\hline 3 & 1.606 & 6.692 & 43.956 & 1.606 & 6.692 & 43.956 \\
\hline 4 & 1.555 & 6.479 & 50.435 & 1.555 & 6.479 & 50.435 \\
\hline 5 & 1.229 & 5.12 & 55.555 & 1.229 & 5.12 & 55.555 \\
\hline 6 & 1.062 & 4.425 & 59.98 & 1.062 & 4.425 & 59.98 \\
\hline 7 & 1.024 & 4.265 & 64.245 & 1.024 & 4.265 & 64.245 \\
\hline
\end{tabular}


Table 5. Reliability analysis and Factor loading matrices

\begin{tabular}{|c|c|c|c|c|c|c|c|c|c|}
\hline Factors & BI & EOU & $\mathrm{AU}$ & SN & PU & PR & $\mathrm{PC}$ & Mean & Std. Dev. \\
\hline 20RBS & 0.802 & & & & & & & 4.23 & 1.574 \\
\hline 19ARF & 0.745 & & & & & & & 3.43 & 1.405 \\
\hline 22WPU & 0.720 & & & & & & & 4.22 & 1.592 \\
\hline $21 \mathrm{NHR}$ & 0.701 & & & & & & & 4.25 & 1.587 \\
\hline $23 \mathrm{AAV}$ & 0.639 & & & & & & & 3.41 & 1.410 \\
\hline 10AAT & & 0.746 & & & & & & 3.68 & 1.479 \\
\hline 09STF & & 0.730 & & & & & & 3.72 & 1.466 \\
\hline 11ERP & & 0.705 & & & & & & 3.14 & 1.513 \\
\hline 08FTR & & 0.702 & & & & & & 3.76 & 1.457 \\
\hline 07APP & & 0.633 & & & & & & 3.71 & 1.485 \\
\hline $12 \mathrm{NWF}$ & & 0.506 & & & & & & 3.13 & 1.508 \\
\hline 29ITU & & & 0.883 & & & & & 4.57 & 1.389 \\
\hline 28WPM & & & 0.819 & & & & & 4.57 & 1.409 \\
\hline 27PLO & & & 0.598 & & & & & 4.55 & 1.398 \\
\hline $24 \mathrm{FNF}$ & & & & 0.803 & & & & 3.54 & 1.545 \\
\hline 26SPA & & & & 0.771 & & & & 3.56 & 1.562 \\
\hline 25PRS & & & & 0.660 & & & & 3.58 & 1.554 \\
\hline 04UPF & & & & & 0.819 & & & 4.90 & 1.282 \\
\hline 03TPF & & & & & 0.750 & & & 4.85 & 1.267 \\
\hline $05 \mathrm{RF}$ & & & & & 0.666 & & & 4.89 & 1.302 \\
\hline 14NEC & & & & & & 0.767 & & 2.94 & 1.461 \\
\hline $17 \mathrm{NFA}$ & & & & & & 0.724 & & 2.93 & 1.462 \\
\hline $13 \mathrm{NOC}$ & & & & & & & 0.763 & 3.41 & 1.440 \\
\hline $18 \mathrm{NSP}$ & & & & & & & 0.754 & 3.45 & 1.423 \\
\hline$\%$ of Variance Explained & 23.281 & 13.983 & 6.692 & 6.479 & 5.12 & 4.425 & 4.265 & & \\
\hline Cronbach's Alpha & 0.833 & 0.792 & 0.778 & 0.681 & 0.674 & 0.754 & 0.527 & & \\
\hline Eigen Value & 5.587 & 3.356 & 1.606 & 1.555 & 1.229 & 1.062 & 1.024 & & \\
\hline
\end{tabular}

To determine the minimum loading necessary to include an item in its respective constructs, loading 0.50 or greater are very significant [21]. For this study, the general criteria were accepted items with loading of 0.506 or greater.

The factor analysis revealed seven factors affiliated from 24 items (Table 5). Generally, the factor is the natural affinity of an item for a group. The higher factor loading indicates the stronger affiliation of an item to a specific factor. The findings of this study indicate that each of the seven factors: behavioral intention (BI), perceived ease of use (EOU), actual use (AU), subjective norms (SN), perceived usefulness (PU), perceived risk (PR) and perceived costs $(\mathrm{PC})$ were homogeneously loaded to the different factors. Each of the items that loaded into nine different factors has proven as significant related to the mobile payment users' expectation.

\subsection{Multiple Regression Analysis}

The performance of regression analysis should be justified with the normality of distribution and no presence of multi-collinearity among the indigenous variables. The normality has been checked through histogram while the multi-collinearity has been examined through tolerance level and VIF value of regression statistics. The tolerance level and VIF value justify the absence of multi-collinearity among the predictors [5] [30]. 
Table 6. Regression Statistics Model

\begin{tabular}{|c|c|c|c|c|c|c|c|c|c|}
\hline \multirow{2}{*}{ Model } & \multirow{2}{*}{$\mathrm{R}^{2}$} & \multirow{2}{*}{$\begin{array}{c}\text { Adjusted } \\
\mathrm{R}^{2}\end{array}$} & \multirow{2}{*}{$\begin{array}{c}\mathrm{F} \\
\text { Value }\end{array}$} & \multirow{2}{*}{ Factors } & \multirow{2}{*}{$\frac{\text { Coefficients }}{\text { Beta }}$} & \multirow{2}{*}{$\mathrm{t}$} & \multirow{2}{*}{ Sig. } & \multicolumn{2}{|c|}{ Collinearity Statistics } \\
\hline & & & & & & & & Tolerance & VIF \\
\hline Model 1 & 0.470 & 0.440 & 84.63 & (Constant) & & 12.11 & 0.000 & & \\
\hline $\begin{array}{c}\text { Dependent Variable: } \\
\text { Actual Use }\end{array}$ & & & & $\begin{array}{l}\text { Behavioral } \\
\text { Intention }\end{array}$ & 0.497 & 9.20 & 0.000 & 1.000 & 1.000 \\
\hline Model 2 & 0.376 & 0.366 & 38.46 & (Constant) & & 4.74 & 0.000 & & \\
\hline \multirow{4}{*}{$\begin{array}{l}\text { Dependent Variable: } \\
\text { Behavioral Intention }\end{array}$} & & & & $\begin{array}{c}\text { Perceived Ease } \\
\text { of Use }\end{array}$ & 0.163 & 3.02 & 0.003 & 0.844 & 1.184 \\
\hline & & & & Perceived Risks & 0.451 & 8.49 & 0.000 & 0.868 & 1.152 \\
\hline & & & & Perceived Costs & 0.219 & 4.19 & 0.000 & 0.893 & 1.120 \\
\hline & & & & $\begin{array}{c}\text { Perceived } \\
\text { Usefulness }\end{array}$ & -0.051 & -0.97 & 0.335 & 0.891 & 1.123 \\
\hline Model 3 & 0.323 & 0.311 & 17.98 & (Constant) & & 15.31 & 0.000 & & \\
\hline \multirow{2}{*}{$\begin{array}{c}\text { Dependent Variable: } \\
\text { Perceived } \\
\text { Usefulness }\end{array}$} & & & & $\begin{array}{c}\text { Perceived Ease } \\
\text { of Use }\end{array}$ & 0.282 & 4.49 & 0.000 & 0.866 & 1.155 \\
\hline & & & & $\begin{array}{l}\text { Subjective } \\
\text { Norms }\end{array}$ & 0.129 & 2.05 & 0.041 & 0.866 & 1.155 \\
\hline Model 4 & 0.34 & 0.31 & 39.90 & (Constant) & & 12.91 & 0.000 & & \\
\hline $\begin{array}{c}\text { Dependent Variable: } \\
\text { Perceived Ease of } \\
\text { Use } \\
\end{array}$ & & & & $\begin{array}{l}\text { Subjective } \\
\text { Norms }\end{array}$ & 0.366 & 6.32 & 0.000 & 1.000 & 1.000 \\
\hline
\end{tabular}

In this study VIF value appeared between 1.000 to 1.155 in four regression models. Again, the tolerance level appeared from 0.844 to 1.000 in five regression models (Table 6). These indicators prove that the predictors in the multiple regression analysis are free from the multi-collinearity. Thus the regression model run should be directly administered for examining the degree and magnitude of the effects of variables. The regression model shows a good fit with $\mathrm{F}$ value of $84.63,38.46,17.98$ and 39.90 are sequentially from model 1 to model 4 . The model 1 run results indicate that behavioral intention considered in the model account for $47 \%$ for mobile payment use by the consumers in Bangladesh.

Again, in model 2 four characteristics (perceived ease of use, perceived risks, perceived costs and perceived usefulness) considered in the model account for $37.6 \%$ mobile payment use intention by the consumers in Bangladesh.

Table 7. Hypotheses Acceptance

\begin{tabular}{|c|c|c|c|c|}
\hline Hypotheses & $\begin{array}{c}\text { Dependent } \\
\text { Factors }\end{array}$ & $\begin{array}{c}\text { Independent } \\
\text { Factors }\end{array}$ & $\begin{array}{c}\mathrm{P} \\
\text { Value } \\
\end{array}$ & Remarks \\
\hline $\mathrm{H}_{1}$ & Actual Use & $\begin{array}{c}\text { Behavioral } \\
\text { Intention }\end{array}$ & 0.000 & Supported \\
\hline $\mathrm{H}_{2}$ & $\begin{array}{c}\text { Behavioral } \\
\text { Intention }\end{array}$ & $\begin{array}{l}\text { Perceived } \\
\text { Usefulness }\end{array}$ & 0.003 & Supported \\
\hline $\mathrm{H}_{3}$ & $\begin{array}{c}\text { Behavioral } \\
\text { Intention }\end{array}$ & $\begin{array}{c}\text { Perceived } \\
\text { Ease of Use }\end{array}$ & 0.335 & $\begin{array}{c}\text { Not } \\
\text { Supported }\end{array}$ \\
\hline $\mathrm{H}_{4}$ & $\begin{array}{l}\text { Perceived } \\
\text { Usefulness }\end{array}$ & $\begin{array}{c}\text { Perceived } \\
\text { Ease of Use }\end{array}$ & 0.000 & Supported \\
\hline $\mathrm{H}_{5}$ & $\begin{array}{c}\text { Perceived } \\
\text { Usefulness }\end{array}$ & $\begin{array}{c}\text { Subjective } \\
\text { Norms }\end{array}$ & 0.041 & Supported \\
\hline $\mathrm{H}_{6}$ & $\begin{array}{c}\text { Perceived } \\
\text { Ease of Use }\end{array}$ & $\begin{array}{c}\text { Subjective } \\
\text { Norms }\end{array}$ & 0.000 & Supported \\
\hline $\mathrm{H}_{7}$ & $\begin{array}{c}\text { Behavioral } \\
\text { Intention }\end{array}$ & $\begin{array}{c}\text { Perceived } \\
\text { Risks }\end{array}$ & 0.000 & Supported \\
\hline $\mathrm{H}_{8}$ & $\begin{array}{c}\text { Behavioral } \\
\text { Intention }\end{array}$ & $\begin{array}{c}\text { Perceived } \\
\text { Costs }\end{array}$ & 0.000 & Supported \\
\hline
\end{tabular}

In model 3 two characteristics (perceived ease of use and subjective norms) considered in the model account for $32.3 \%$ on perceived usefulness; and subjective norms in model 4 considered $34 \%$ on perceived ease of use by the mobile payment consumers in Bangladesh. The study showed that eight hypotheses were supported out of eleven hypotheses significant at $\mathrm{p}<0.05$ (Table 7).

\section{Conclusions and Implications}

This study was attempted to examine and understand the consumers' behavioral intention and use behavior towards mobile payment services in Bangladesh. The mobile payment service providers are characterized by the involvement in making awareness and educating to use their mobile payment services. Presently, they are highly competing for providing diverse mobile payment services along with network quality and network extension for making network loyal customers. According to this study, behavioral intention is the highest significant factor to influence actual use of mobile payment for the consumers in Bangladesh. Again, perceived risk is the highest significant factor to influence behavioral intention following perceived costs and perceived ease of use. Finally, subjective norms affect significantly to mediate perceived usefulness and perceived ease of use to influence behavioral intention to use of mobile payment services in Bangladesh.

The primary theoretical contribution of this study is the identification of factors that can be used to enlighten and foretell consumers' intention and use of mobile payment services, particularly within the Bangladesh context. This research also creates a research interest on mobile payment for the business researchers. Again, perceived risk and perceived costs have been found as strong factors of TAM 
model relevant to mobile payment services in Bangladesh. Finally, it has found that people are very much interested to involve in mobile payment use those are day to day business to customer (B2C) payment like transportation ticket purchase, utility bill payment, money transfer for personal \& business purposes, and online shopping of home appliances. So, the findings of the study can help mobile payment services providers in their operation and strategic plan of marketing of mobile VAS applications.

\subsection{Limitation and Future Research}

The sample size of this study was not necessarily representative of the Bangladeshi population as a whole as it ignored same number of population from different regions. Secondly, the generalizability of this research may be impacted by fact that the sample's is skewed towards males. In terms of future research, a large scale study with more representative sample could be conducted to measure the degree of impact of the different drivers and barriers in the acceptance of mobile payment to enhance the generalizability of the research conclusions.

Mobile payment service is very new to Bangladeshi consumers and it is still at early stages in Bangladesh. The current target market for mobile payment customer is relatively small due to the lack of expanded use of mobile payment in online merchants, banks, MFS, and MNOs. There is a good potential for introducing mobile payment service in Bangladesh. This research has served to enhance the understanding of the impact drivers and barriers to influence consumers' acceptance towards mobile payment use it in the context of Bangladesh. It has demonstrated that there were multiple impact factors at work for influencing the consumers and that some are more influential under given circumstances. The knowledge gained by this study into the motivators and inhibitors of mobile payment is useful for practitioners who aim to maximize consumers' interest and business expansion at mobile payment use of B2C services in Bangladesh.

\section{REFERENCES}

[1] (2010). Retrieved from The iResearch: http://www.iresearch. com.cn/

[2] Alda's-Manzano, J., R.-M., \& Sanz-Blas, S. (2009). Exploring individual personality factors as drivers of M-shopping acceptance. Industrial Management \& Data Systems, 109(6), 739-757.

[3] Amin, H., M. R. A., H., S, L., \& Z. , A. (2008). The adoption of mobile banking in Malaysia: The case of Bank Islam Malaysia Berhad. International Journal of Business and Society, 9(2), 43-53.

[4] Anckar, B., \& D'Incau, D. (2002). Value-added services in mobile commerce: An analytical framework and empirical findings from a national consumer survey. 35th Annual Hawaii International Conference (HICSS) (pp. 1444-1453). Hawaii : In System Sciences.

[5] Azam, M. (2007). Internet Adoption and Usage in Bangladesh. Japanese Journal of Administrative Science, 20(1), 43-54.

[6] Bauer, H., Reichardt, T., Barnes, S., \& Neumann, M. (2005). Driving consumer acceptance of mobile marketing: A theoretical framework and empirical study. Journal of electronic commerce research, 6(3), 181-192.

[7] Beatty, R., Shim, J., \& Mary, C. (2001). Factors influencing corporate web site adoption: a time-based assessment. Information \& management, 38(6), 337-354.

[8] Berg, E., Mörtberg, C., \& Jansson, M. (2005). Emphasizing technology: socio-technical implications. Information Technology \& People, 18(4), 343-358.

[9] Bhatti, T. (2007). Exploring factors influencing the adoption of mobile commerce. Journal of Internet Banking and Commerce, 12(3), 1-13.

[10] Bmoninfo. (2012). Total Internet Subscribers at the end of February 2012. Dhaka: Bangladesh Mobile Operators News.

[11] Chau, P., \& Hu, P. (2001). Information Technology Acceptance by Individual Professionals: A Model Comparison Approach. Decision Sciences, 32(4), 699-719.

[12] Chen, L., Gillenson, M., \& Sherrell, D. (2004). Consumer acceptance of virtual stores: a theoretical model and critical success factors for virtual stores. ACM SIGMIS Database, 35(2), 8-31.

[13] Cheong, J., \& Park, M. (2005). Mobile internet acceptance in Korea. Internet Research, 15(2), 125 - 140.

[14] Dasgupta, S., R., P., \& S., F. (2011). Factors affecting behavioral intentions towards mobile banking usage: Empirical evidence from India. Romanian Journal of Marketing, 3(1), 6-28.

[15] Davis, F. D. (1989). Perceived Usefulness, Perceived Ease of Use, and User Acceptance of Information Technology. MIS Quarterly, 13(3), 319-340.

[16] Davis, F., Bagozzi, R., \& Warshaw, P. (1989). User acceptance of computer technology: a comparison of two theoretical models. Management Science, 35(8), 982-1003.

[17] Dell'Era, C., Frattini, F., \& Ghezzi, A. (2013). The role of the adoption network in the early market survival of innovations: The case of the Italian mobile value-added services (VAS) industry. European Journal of Innovation Management, 16(1), 118-140.

[18] G. R., D., \& R., S. (1994). A model of perceived risk and intended risk-handling activity. Journal of Consumer Research, 21, 119-134.

[19] GSMA Intelligence. (2014). ANALYSIS Country overview: Bangladesh. London: GSMA.

[20] Ha, I., Yoon, Y., \& Choi, M. (2007). Determinants of adoption of mobile games under mobile broadband wireless access environment. Information \& Management, 44(3), 276-286.

[21] Hair, J., Anderson, R., Tatham, R., \& Black, W. (1992). Multivariate Data Analysis (3rd ed.). New York: Macmillan. 
[22] Hamed, Z., Ramin, Qadim, \& Vatanparast. (2009). A CROSS-CULTURAL STUDY ON MOBILE INTERNET USAGE. International Journal of Mobile Marketing, 4(2), $14-27$.

[23] HAUSER, J. R., \& SHUGAN, S. (1980). Intensity Measures of Consumer Preference. Operation Research, 28(2), 278-320

[24] Holak, S. L., \& Lehmann, D. R. (1990). Purchase intentions and the dimensions of innovation: An exploratory model. Journal of Product Innovation Management, 7(1), 59-73.

[25] Hu, P., Chau, P., Sheng, O., \& Tam, K. (1999). Examining the technology acceptance model using physician acceptance of telemedicine technology. Journal of Management Information Systems, 16(2), 91-112.

[26] Internet Usage in Asia. (2015, December 12). Retrieved from Internet World Stats: http://www.internetworldstats.com/stat s3.htm

[27] Internet users. (2016, March 22). Retrieved from The World Bank Data: http://data.worldbank.org/indicator/IT.NET.USE R.P2

[28] Islam, M. M., \& Hossain, M. E. (2013). University Students Attitudes towards Mobile Internet Uses: A Study on Four Universities in Northern Region of Bangladesh. 1st International Conference on Entrepreneurship, SMEs Development and Management (pp. 274-281). Rajshahi: Faculty of Business Studies, University of Rajshahi and UKM-CESMED.

[29] J.H., W., \& S.C., W. (2005). What drives mobile commerce? An empirical evaluation of the revised technology acceptance model. Information \& Management, 42, 719-729.

[30] Kendall, J., Tung, L., Chua, K., Ng, C., \& Tan, S. (2001). Receptivity of singapore's SMEs to electronic commerce adoption. Journal of Strategic Information Systems, 10, 223-242.

[31] Kim, D., \& Steinfield, C. (2004). Consumers Mobile Internet Service Satisfaction and their Continuance Intentions. Americas Conference on Information Systems (AMCIS). AIS Electronic Library (AISeL).

[32] Klein, R. (2007). An empirical examination of patient-physician portal acceptance,. European Journal of Information Systems, 16(6), 751-760.

[33] Klopping, I., \& McKinney, E. (2004). Extending the technology acceptance model and the task-technology fit model to consumer e-commerce. Information Technology, Learning, and Performance Journal, 22(1), 35-48.

[34] Koening-Lewis, N., A., P., \& A., M. (2010). Predicting young consumers' take up of mobile banking services,. International Journal of Banking Marketing, 28(5), 410-432.

[35] Kretchun, N. (2015). Mobile Money in Bangladesh: Still a Long Way to Go. Washington DC: CGAP.

[36] Kumar, A., \& Lim, H. (2008). Age differences in mobile service perceptions: comparison of Generation Y and baby boomers. Journal of Services Marketing, 22(7), 568-577.

[37] Kuo, Y., \& S., Y. (2009). Towards an understanding of the behavioral intention to use $3 \mathrm{G}$ mobile value-added services. Computers in Human Behavior, 25, 103-110.
[38] Kuo, Y., \& Yen, S. (2009). Towards an understanding of the behavioral intention to use $3 \mathrm{G}$ mobile value-added services. Computers in Human Behavior, 25(1), 103-110.

[39] L, C. (2008). A model of consumer acceptance of mobile payment. International Journal of Mobile Communications, 6 , $32-52$.

[40] Labay, D. G., \& Thomas, C. K. (1981). Exploring the consumer decision process in the adoption of solar energy systems. Journal of Consumer Research, 271-278.

[41] Lee, W. J., Kimb, T. U., \& Chung, J. (2002). USER ACCEPTANCE OF THE MOBILE INTERNET. Athens: M-Business:Citeseer.

[42] Liu, Y., \& Li, H. (2010). Mobile internet diffusion in China: an empirical study. Industrial Management \& Data Systems, $110(3), 309-324$.

[43] López-Nicolás, C., Molina-Castillo, F., \& Bouwman, H. (2008). An assessment of advanced mobile services acceptance: Contributions from TAM and diffusion theory models. Information \& Management, 45(6), 359-364.

[44] Lu, J., Yao, E. J., \& Yu, C. (2005). Personal innovativeness, social influences and adoption of wireless Internet services via mobile technology. Journal of Strategic Information Systems, 14, 245-268.

[45] M., C. (2007). Mobile Payment systems and services: An introduction. Mobile Payment Forum.

[46] Mallat, N., Rossi, M., Tuunainen, V., \& Öörni, A. (2008). An empirical investigation of mobile ticketing service adoption in public transportation. Personal and Ubiquitous Computing, $12(1), 57-65$

[47] Mallat, N. (2007). Exploring consumer adoption of mobile payments: A qualitative study. The Journal of Strategic Information Systems, 16, 413-432.

[48] Mallat, N., Rossi, M., Tuunainen, V., \& Öörni, A. (2009). The impact of use context on mobile services acceptance: The case of mobile ticketing. Information \& management, 46(3), 190-195.

[49] McCoya, S., Everardb, A., \& Jonesc, B. (2005). An Examination of the Technology Acceptance Model in Uruguay and the US: A Focus on Culture. Journal of Global Information Technology Management, 8(2), 27-45.

[50] Mills, A., Tennant, V., \& Chevers, D. (2011). Understanding Mobile Internet Diffusion: The Case of Jamaica. GlobDev 2011, (p. Paper 6).

[51] N., A. (2010). The impact of user acceptance of mobile payment services: An empirical analysis,. Shanghai, China: East China University of Science and Technology.

[52] Nabi, M., Chen, G., \& Banerjee, S. (2012). Mobile Financial Services in Bangladesh: An Overview of Market Development. Dhaka: Bangladesh Bank.

[53] Nysveen, H., Pedersen, P., \& Thorbjørnsen, H. (2005). Intentions to Use Mobile Services: Antecedents and Cross-Service Comparisons. Journal of the Academy of Marketing Science, 33(3), 330-346.

[54] O'Leary-Kellya, S., \& Vokurkaa, R. (1998). The empirical assessment of construct validity. Journal of Operations Management, 6(4), 387-405. 
[55] Ostlund, L. (1973). Perceived Innovation Attributes as Predictors of Innovativeness. Journal of Consumer Research, 1, 23-29.

[56] P., L., \& H.H. , L. (2005). Toward an understanding of the behavioral intention to use mobile banking. Computers in Human Behavior, 21, 873-891.

[57] P.A., P. (2003). Consumer acceptance of electronic commerce: Integrating trust and risk with the technology acceptance model. International Journal of Electronic Commerce, 7, 101-134.

[58] Pagani, M. (2004). DETERMINANTS OF ADOPTION OF THIRD GENERATION MOBILE MULTIMEDIA SERVICES. JOURNAL OF INTERACTIVE MARKETING, 18(3), 46-59.

[59] Pedersen, P. (2005). Adoption of Mobile Internet Services: An Exploratory Study of Mobile Commerce Early Adopters. JOURNAL OF ORGANIZATIONAL COMPUTING AND ELECTRONIC COMMERCE, 15(2), 203-222.

[60] Plouffe, C., Vandenbosch, M., \& Hulland, J. (2001). Intermediating Technologies Multi-Group Adoption: A Comparison of Consumer and Merchant Adoption Intentions toward a New Electronic Payment System. Journal of Product Innovation Management, 18(2), 65-81.

[61] Ramírez-Correa, P., \& Rondán-Cataluña, F. (2014). An empirical analysis of mobile Internet acceptance in Chile. Information Research, 19(3).

[62] Revels, J., Tojib, D., \& Tsarenko, Y. (2010). Understanding consumer intention to use mobile services. Australasian Marketing Journal (AMJ), 18(2), 74-80.

[63] Riquelme, H., \& R. E., R. (2010). The moderating effect of gender in the adoption of mobile banking. International Journal of Bank Marketing, 28(5), 328-341.

[64] Roberts, J. (2013, May 22). Mobile payments. Retrieved November 17, 2015, from Mobile Transaction: http://www.mobiletransaction.org/growth-mobile-payments/

[65] Rogers, E. (1995). Diffusion of Innovation (4th ed.). New York: Free Press.

[66] Selvamalar, A. (2015). The rise of mobile payment. Singapore: TECHINASIA.

[67] Shatskikh, A. (2013). Consumer Acceptance of Mobile Payments in Restaurants. Florida: Graduate School Theses, University of South Florida,.

[68] Sirasoontorn, P. (2010). Economic analysis of business model for delivering mobile value-added services in Thailand. Available at SSRN 1618174.

[69] Sripalawat, J., M., T., \& A., N. (2011). M-banking in metropolitan Bangkok and a comparison with other countries. The Journal of Computer Information Systems, 51(3), 67-76.

[70] Staff, R. (2013). Why does Kenya lead the world in mobile money? London: The Economist.

[71] Stalfors, P., \& Nykvist, R. (2011). Consumer Acceptance of Mobile Payment Services. HANDELSHÖGSKOLAN VID
GÖTEBORGS UNIVERSITET, Department of Business Administration. HANDELSHÖGSKOLAN VID GÖTEBORGS UNIVERSITET.

[72] Strategic Review of Mobile Value-Added Services (M-VAS) Opportunity Based On Customer Satisfaction and Loyalty Criteria in Indonesia. (n.d.).

[73] T., D., Mallat, N., Ondrus, J., \& Zmijewska, A. (2008). Past, present and future of mobile payments research: A literature review,. Electronic Commerce Research and Applications, 7, 165-181.

[74] Tanner, J. C. (2012). Innovative ways to make mobile pay. Causeway Bay, Hong Kong: telecomasia.net.

[75] Teo, T., \& Pok, S. (2003). Adoption of WAP-enabled mobile phones among Internet users. The International Journal of Management Science, 31, 483-498.

[76] Timothy, T., Perry, Leslie, A., \& Karen, H. (1998). Internet use by university students: an interdisciplinary study on three campuses. Internet Research, 8(2), 136 - 141.

[77] Touraya, A., Salminena, A., \& Mursub, A. (2015). Internet Adoption at the User Level: Empirical Evidence from The Gambia. Information Technology for Development, 21(2), 281-296.

[78] Uddin, M., \& Akhter, B. (2012). CUSTOMER SATISFACTION IN MOBILE PHONE SERVICES IN BANGLADESH: A SURVEY RESEARCH. Management \& Marketing Journal, 10(1), 20-36.

[79] Venkatesh, V., \& Davis, F. (2000). A theoretical extension of the technology acceptance model: Four longitudinal field studies. Management science, 46(2), 186-204.

[80] Verkasalo, H. (2009). Analysis of mobile internet usage among early-adopters. Emerald Group Publishing Limited, 11(4), 68-82.

[81] W., T., H., L., \& H., Y. (2009). Exploring the mass adoption of third-generation (3G) mobile phones in Taiwan. Telecommunications Policy, 33, 628-641.

[82] Wang, H., Chan, T., Huang, Y., Wang, N., \& Chang, Y. (2010). Research Hypotheses for Gender Activities in Mobile Internet. IWCMC'10. Caen, France.

[83] Wang, W., \& Li, H. (2012). Factors influencing mobile services adoption: a brand-equity perspective. Internet Research, 22(2), 142-179.

[84] Wu, Y., \& Tsai, C. (2006). University Students' Internet Attitudes and Internet Self-Efficacy: A Study at Three Universities in Taiwan. CYBERPSYCHOLOGY \& BEHAVIOR, 9, 441-450.

[85] Yi, M., Jackson, J., Park, J., \& Probst, J. (2006). Understanding information technology acceptance by individual professionals: Toward an integrative view. Information \& Management, 43(3), 350-363.

[86] Zhou, T. (2011). Understanding mobile Internet continuance usage from the perspectives of UTAUT and flow. Information Development, 27(3), 207-218. 